\title{
PERBANDINGAN RERATA EKSPRESI PROTEIN Bax DAN Bak PADA PREEKLAMPSIA BERAT DAN KEHAMILAN NORMOTENSI
}

\author{
Tejo Sujatmiko*, Diah Rumekti H*, Detty S Nurdiati*
}

\begin{abstract}
Background: Preeclampsia is still become major cause of maternal and perinatal mortality. The placenta is an important and central focus on the pathogenesis of preeclampsia. Failure of trophoblast cells to perform remodeling on spiral arteries due to excessive apoptosis may cause uteroplacental ischemia and endothelial cells damage, this induce clinical manifestations of preeclampsia especially through the intrinsic pathway. Intracellular Bax and Bak are genes that play a role as a cells apoptosis regulator (as proapoptosis). They are located in the mitochondria and endoplasmic reticulum and would in turn activate caspase the intrinsic apoptotic pathway that cascade resulting in cell death processes.

Objective: Comparing the mean of Bax and Bak protein expression between normotensive pregnancies and severe preeclampsia.

Method: This research is a cross-sectional study design. The subjects were severe preeclampsia and normotensive patients treated at RSUP dr. Sardjito Jogjakarta between October 2011 to March 2012, with total patients of 81 . Bak and Bax protein expression were measured with immunohistochemistry techniques.

Result and Discussion: The mean expression of Bax and Bak proteins in severe preeclampsia group were significantly higher compared to normotensive group. The mean value of Bax expression was 0,23 (Cl 95 $\% 0,12-0,34)$ and the mean expression of Bak was 0,44 (95\% Cl 0,10-0,78).
\end{abstract}

Conclusion: Expression of Bax and Bak proteins in severe preeclampsia is higher than normotensive pregnancies and Bax protein gave more effect statistically in preeclampsia compared to Bak protein.

Keywords: trophoblast, immunohistochemistry, severe preeclampsia, Bak protein, Bax protein, apoptosis.

\section{ABSTRAK}

Latar belakang: Preeklampsia masih merupakan penyebab kematian maternal dan perinatal yang utama. Plasenta merupakan fokus sentral dan penting pada patogenesis terjadinya preeklampsia. Kegagalan sel trofoblas melakukan remodeling arteri spiralis akibat proses apoptosis yang berlebihan menyebabkan terjadinya iskemia uteroplasenter dan kerusakan sel endotel yang menimbulkan manifestasi klinis preklampsia terutama terjadi melalui jalur intrinsik intraseluler dimana Bax dan Bak adalah gen-gen yang berperan sebagai regulator apoptosis pada sel (sebagai pro-apoptosis). Mereka terletak di dalam mitokondria dan reticulum endoplasma dan bekerja mengaktifkan caspase cascade sehingga terjadi proses kematian sel.

Tujuan: Membandingkan rerata ekspresi protein Bax dan Bak antara preeklampsia berat dengan kehamilan normotensi.

* Departement of obstetrics and gynecology

* Medical Faculty of Gadjah Mada University

* Sardjito Hospital 
Metode: Penelitian ini merupakan rancangan penelitian potong lintang dengan sampel penderita preeklampsia berat dan normotensi yang dirawat di RSUP dr. Sardjito Jogjakarta antara bulan Oktober 2011 hingga Maret 2012, sebanyak 81 pasien. Pengamatan ekspresi protein Bak dan Bax dilakukan dengan teknik imunohistokimia.

Hasil dan Pembahasan: Rerata ekspresi protein Bax dan Bak pada kelompok preeklampsia berat lebih tinggi secara bermakna di bandingkan kelompok normotensi Dengan nilai rerata ekpresi Bax 0.23 (Cl 95\% 0.12 - 0.34) dan rerata ekspresi Bak 0.44 (Cl 95\% $0.10-0.78$ ).

Kesimpulan: Ekspresi protein Bax dan Bak pada preeklampsia berat lebih tinggi dibanding dengan kehamilan normotensi dan protein Bax lebih berpengaruh pada preeklampsia dibanding dengan protein Bak.

Kata kunci: trofoblas, imunohistokimia, preeklampsia berat, protein Bak, protein Bax, apoptosis.

\section{PENDAHULUAN}

Preeklampsia masih merupakan penyebab kematian maternal dan perinatal yang utama. Dalam prakteknya preeklamsia dapat kita diagnosis dengan adanya hipertensi dan proteinuria dalam kehamilan. Penyebab preeklampsia dan eklamsia saat ini masih merupakan disease of theory.

Angka kejadian preeklampsia di Indonesia pada tahun 1980-2001 berkisar antara 5-8\% dari seluruh kehamilan. Di RSUP DR. Sardjito angka kematian maternal karena preeklampsiaeklampsia adalah sebesar 34,09\%. ${ }^{1,2}$

Walaupun penyebabnya masih belum diketahui dengan pasti, namun terdapat beberapa teori terjadinya preeklamsia, antara lain (1) Faktor maladaptasi imunologi, dimana terjadinya mal adaptasi imun dapat menyebakan dangkalnya invasi sel trofoblas pada arteri spiralis. Terjadinya disfungsi endotel dipicu oleh pembentukan sitokin, enzim proteolitik dan radikal bebas. (2) Iskemia placenta, dimana peningkatan deportasi sel trofoblas yang akan menyebabkan kegagalan invasi ke arteri spiralis dan akan menyebabkan iskemia pada placenta. (3) Penyakit pembuluh darah. (4) Genetic imprinting, didasarkan pada gen resesif tunggal atau dominant dengan penetrasi yang tidak sempurna. ${ }^{3,4}$ Faktor di atas menyebabkan arteri spiralis tidak dapat berdilatasi dengan sempurna dan mengakibatkan turunnya aliran darah di plasenta yang akan diikuti dengan terjadinya stres oksidatif, peningkatan radikal bebas, disfungsi endotel, agregasi dan penumpukan trombosit yang dapat terjadi di berbagai organ yang memacu terjadinya preeklamsia. ${ }^{4,5,10}$

Perkembangan plasenta secara normal tergantung pada diferensiasi dan invasi trofoblas,sebagai komponen utama plasenta. Apoptosis trofoblas meningkat sejalan dengan bertambahnya usia plasenta. Apoptosis dapat diidentifikasi di plasenta baik dari sisi ibu maupun janin, dan munculnya apoptosis berhubungan dengan stadium pertumbuhan plasenta, yaitu perlekatan dan infasi trofoblas, transformasi arteri spiralis, diferensiasi trofoblas serta pergatian sel yang rusak. ${ }^{6}$

Apoptosis, suatu bentuk kematian sel terprogram, telah dideskripsikan pada plasenta dari kehamilan manusia normal dan meningkat pada kehamilan dengan restriksi pertumbuhan fetus.

Bax dan Bak adalah gen-gen yang berperan sebagai regulator apoptosis pada sel (sebagai pro- 
apoptosis). Mereka terletak di dalam mitokondria dan reticulum endoplasma dan mengaktifkan kaspase untuk mengatur jalur apoptosis. ${ }^{7,8}$

Hung membandingkan ekspresi 5 protein $\mathrm{Bcl}-2$ family yaitu Bcl-2, Bcl-xl, Bax, Bak dan Bad setelah suatu jaringan plasenta dari kehamilan normal dikultur dalam suasana hipoxia ( $2 \% \mathrm{O} 2)$, prolonged hypoxia-reoxygenation (HR), dan normosik (8\% O2) sebagai kontrol. Hasilnya didapatkan peningkatan ekspresi Bax, dan Bak mRNA, dan penurunan ekspresi Bcl-2 mRNA. ${ }^{9}$

Pada preeklampsia ekspresi protein Bax dan Bak sama-sama meningkat, tetapi protein mana yang lebih tinggi peningkatanya belum dijelaskan. Oleh karena itu peneliti ingin mengetahui ekspresi protein dari golongan pro apoptosis mana yang lebih tinggi peningkatanya pada penderita preeklampsia.

\section{METODE}

Penelitian ini merupakan studi cross sectional (potong lintang) dengan teknik imunohistokimia untuk pengamatan ekspresi protein Bax dan Bak. Sampel jaringan trofoblas berasal dari biopsi jaringan plasenta preeklampsia berat, dibandingkan dengan kehamilan normotensi $(n=81)$.

\section{Pembuatan slide jaringan}

Jaringan trofoblas hasil biopsi difiksasi pada formalin $10 \%$. Setelah itu dilakukan dehidrasi menggunakan alkohol bertingkat (30\%, 50\%, $70 \%, 80 \%, 96 \%$ dan absolut) masing-masing 60 menit. Dilakukan Clearing menggunakan xilol 2 kali masing-masing 60 menit. Kemudian dilakukan infiltrasi dengan parafin lunak selama 60 menit pada suhu $48^{\circ} \mathrm{C}$. Kemudian dilakukan block dalam parafin keras pada cetakan dan didiamkan selama sehari. Keesokan harinya ditempelkan pada holder dan dilakukan pemotongan setebal 4-6 $\mu \mathrm{m}$ dengan rotary microtome. Dilakukan mounting pada gelas objek dengan gelatin $5 \%$. Gelas objek hasil parafin block direndam dalam xilol 2 kali masing-masing selama 5 menit. Setelah itu dilakukan rehidrasi menggunakan alkohol berseri (absolut, 96\%, 80\%, 70\%, 50\% dan 30\%) masing-masing selama 5 menit. Kemudian dibilas dalam dH2O selama 5 menit.

\section{Imunohistokimia protein Bax dan Bak}

Slide dicuci dengan PBS pH 7,4 satu kali selama 5 menit. Blocking endogenous peroksida menggunakan 3\% H2O2 selama 20 menit. Cuci menggunakan PBS pH 7,4 tiga kali, selam 5 menit. Blocking unspecific protein menggunakan $5 \%$ PBS yang mengandung 0,25\% Triton X-100. Cuci menggunakan PBS pH 7,4 tiga kali, selama 5 menit. Inkubasi menggunakan mouse monoclonal anti Bax dan Bak selama 60 menit. Cuci menggunakan PBS pH 7,4 tiga kali, selama 5 menit. Tetesi dengan trekki universal link selama 10 menit kemudian cuci dengan PBS pH 7.4 tiga kali selama 5 menit. Tetesi dengan Betazoid DAB (Diamino Benzidine) selama 15 menit. Cuci dengan aquades 5 menit. Counterstaining menggunakan Mayer Hematoxilen yang diinkubasi selama 10 menit dan cuci dengan air mengalir. Dehidrasi dengan alkohol 50\%, 70\%, 80\%, 90\%, 95\% dan alkohol absolut selama 5 menit kemudian dilanjutkan dengan xylene I, II dan III selama $3 \times 3$ menit. Mounting menggunakan entelan dan tutup dengan cover glass. Ekspresi protein Bax dan Bak dilihat dengan menggunakan mikroskop cahaya pada daerah desidua dengan pembesaran kuat (400X) di lima lapangan pandang dan ekspresi protein Bax dan Bak dikatakan positif jika diadapatkan warna coklat pada sitoplasma dan atau membran sel. 


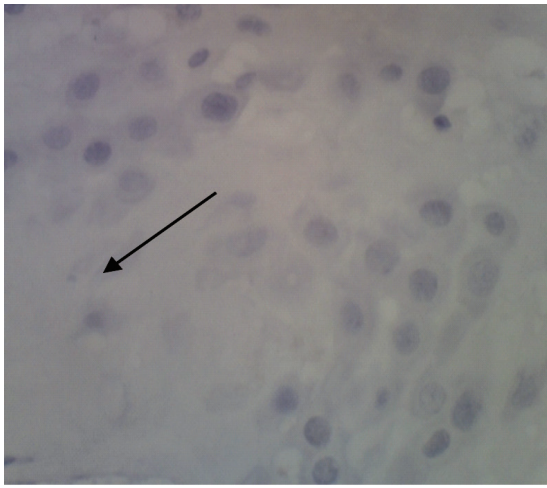

Ekspresi Bax dengan intensitas O

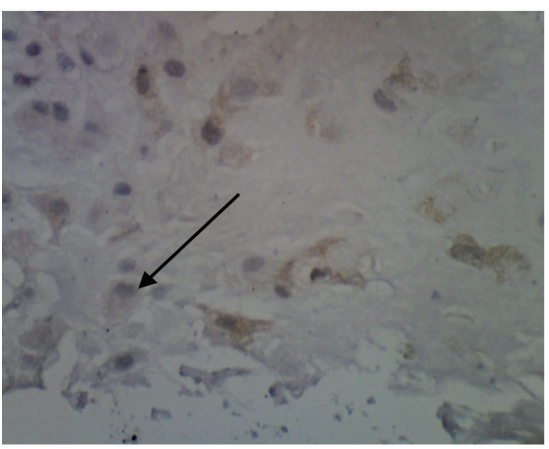

Ekspresi Bax dengan intensitas 2

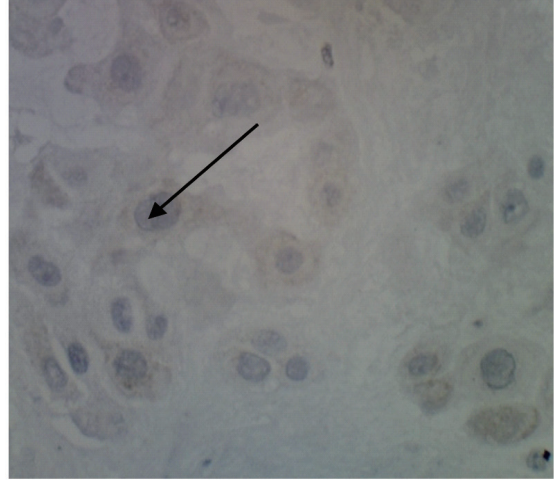

Ekspresi Bax dengan intensitas 1

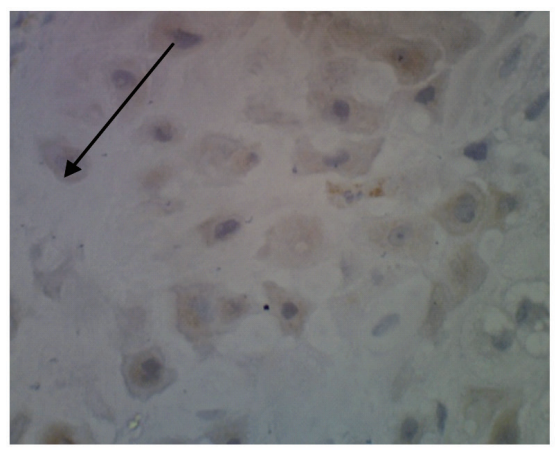

Ekspresi Bax dengan intensitas 3

Gambar 1. Intensitas warna pengecatan protein Bax

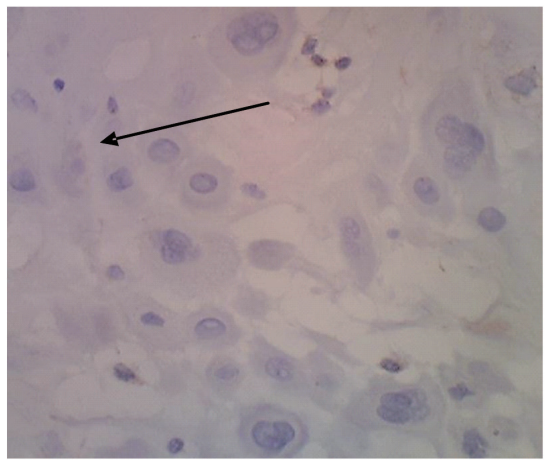

Ekspresi Bak dengan intensitas $\mathrm{O}$

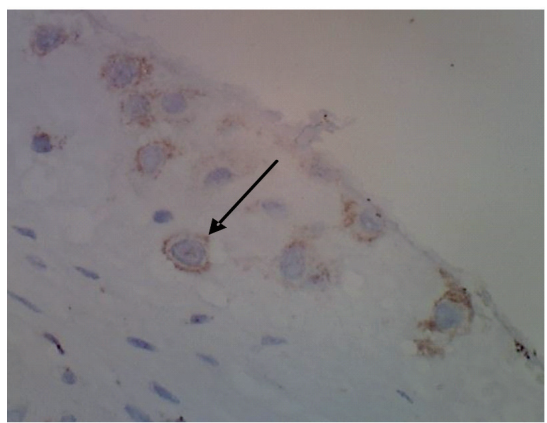

Ekspresi Bak dengan intensitas 2

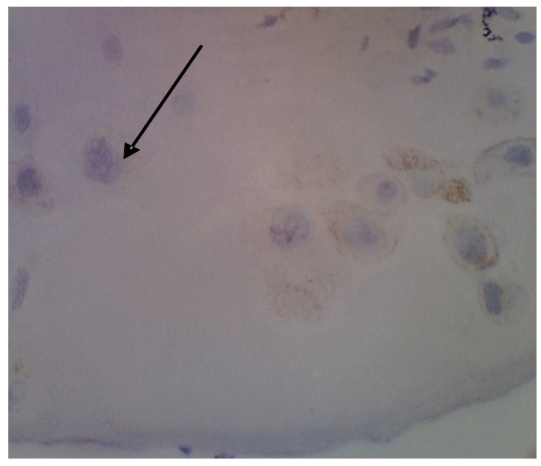

Ekspresi Bak dengan intensitas 1

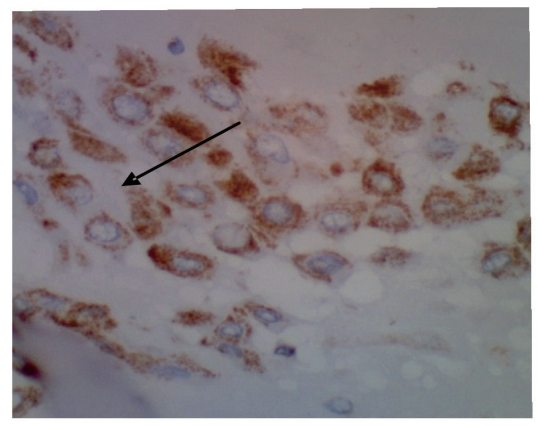

Ekspresi Bak dengan intensitas 3

Gambar 2. Intensitas warna pengecatan protein Bak 


\section{HASIL DAN PEMBAHASAN}

Sampel penelitian diperoleh dari pasien yang dirawat dan melakukan persalinan di RS dr. Sardjito Jogjakarta, selama 6 bulan yang dimulai pada bulan Oktober 2011 sampai dengan bulan Maret 2012. Didapatkan sampel penelitian 81 plasenta.

Tabel 1. karakteristik subyek kedua kelompok penelitian

\begin{tabular}{cccc}
\hline \multirow{2}{*}{ Variabel } & $\begin{array}{c}\text { Preeklampsia Berat } \\
(\mathrm{n}=43)\end{array}$ & $\begin{array}{c}\text { Normotensi }(\mathrm{n} \\
=38)\end{array}$ & $\mathrm{P}$ \\
\cline { 2 - 3 } & Mean \pm SD & Mean \pm SD & \\
\hline Usia ibu & $28,4 \pm 6,8$ & $28,4 \pm 7,1$ & 0,97 \\
Paritas & $0,6 \pm 0,8$ & $1,0 \pm 1,3$ & 0,13 \\
Usia & $36,0 \pm 2,5$ & $38,6 \pm 1,1$ & 0,00 \\
Kehamilan & $166,7 \pm 20,8$ & $114,2 \pm 7,2$ & 0,00 \\
Sistolik & $106,4 \pm 17,4$ & $76,3 \pm 6,7$ & 0,00 \\
Diastolik & $126,5 \pm 16,8$ & $88,7 \pm 6,4$ & 0,00 \\
MAP & $28,1 \pm 5,4$ & $25,9 \pm 4,3$ & 0,06 \\
BMI & &
\end{tabular}

Ekspresi protein Bax dan Bak diukur dengan cara semiquantitative imuno-histochemical scoring system (HSCORE) dengan rumus penghitungan HSCORE $=\sum \mathrm{Pi}(i+1)$, dimana $\mathrm{Pi}$ adalah prosentase jumlah sel yang positif dengan pengecatan Bak sedangkan $\mathrm{i}$ adalah intensitas warna pengecatan dengan nilai $0=$ negatif, $1=$ positif lemah, 2 = positif sedang dan 3 = positif kuat. Perhitungan nilai HSCORE ekspresi protein Bax dan Bak masing-masing dilakukan oleh dua orang pengamat dengan merahasiakan identitas sampel yang diamati, kemudian dilakukan uji kesesuaian antar observer dengan uji intra class corelation. pada uji intra class corelation nilai HSCORE ekspresi protein Bax di dapatkan nilai intra class corelation 0.9 dan untuk nilai HSCORE ekspresi protein Bak di dapatkan nilai intra class corelation 0.9. Dari nilai uji intra class corelation kedua ekspresi protein tersebut menunjukkan adanya kesesuaian yang kuat diantara kedua observer.

Tabel 2. Hubungan ekspresi protein Bax dan ekspresi protein Bak, terhadap preeklampsia berat dan kehamilan normotensi

\begin{tabular}{ccccc}
\hline Variabel & $\begin{array}{c}\text { Preeklampsia Berat/ } \\
\text { Eklampsia }(\mathrm{n}=43)\end{array}$ & $\begin{array}{c}\text { Normotensi } \\
(\mathrm{n}=38)\end{array}$ & $\begin{array}{c}\text { Perbedaan rerata } \\
(\mathrm{Cl} 95 \%)\end{array}$ & $\mathrm{P}$ \\
\cline { 2 - 3 } & Mean $\pm \mathrm{SD}$ & Mean \pm SD & & \\
\hline Ekspresi Bax & $1.67 \pm 0.22$ & $1.44 \pm 0.26$ & $\begin{array}{c}0.23 \\
(0.12-0.34)\end{array}$ & 0.00 \\
\hline Ekspresi Bak & $2.36 \pm 0.90$ & $1.92 \pm 0.58$ & $\begin{array}{c}0.44 \\
(0.10-0.78)\end{array}$ & 0.01 \\
\hline
\end{tabular}


Pada preeklampsia invasi trofoblas yang tidak komplit, menyebabkan pembuluh darah desidua akan dilapisi oleh trofoblas endovaskular, tapi tidak mempengaruhi lapisan endotel dan lapisan muskularis arteri miometrium yang lebih dalam. Oleh karena remodelling yang gagal ini maka diameter arteriol pada preeklampsia menjadi $1 / 2$ diameter pada kehamilan normal. ${ }^{10}$

Jalur mitokondria di induksi sebagai respons terhadap stress selluler dan menyebabkan aktivasi protein pro-apoptotic BH3-only yang akan berikatan dan mengaktivasi Bax dan Bak. Sekali teraktivasi, oligomer Bax dan Bak akan membentuk celah di membran luar mitokondria untuk merilis keluarnya Cytochrome C. Caspase akan diaktivasi oleh adanya Cytochrome c sitosol diikuti dengan tahapan-tahapan apoptosis dengan kematian sel. ${ }^{11}$ Ada tiga bukti mengenai ekspresi Bax dan Bak pada kehamilan. Pertama, ekspresi Bax dan Bak sangatlah terlihat pada sitotrofoblas, stroma, sel-sel endotelial dan desidua plasenta pada aborsi trimester pertama dibandingkan imunopositifitas Bax dan Bak rendah / sedang pada semua kompartemen plasenta selama terminasi kehamilan sukarela pada trimester pertama. Kedua, Imunopositifitas Bax dan Bak pada kelahiran spontan trimester ketiga lebih terlihat dibandingkan dengan kelahiran caesarean trimester ketiga. Ketiga, ada peningkatan ekspresi Bax dan Bak pada plasenta yang mengalami preeklamsia dibandingkan plasenta normal aterm. ${ }^{12}$ Pada jaringan plasenta normal yang dilihat dengan mikroskop cahaya pada kehamilan trimester pertama dan trimester tiga teridentifikasi 0,15\% mengalami apoptosis. ${ }^{13}$ Penelitian yang dilakukan Keman, didapatkan jumlah sel trofoblas penderita preeklampsia berat yang mengekspresikan apoptosis lebih tinggi $(4,70 \pm 1,829 ; p=0,000)$ dibandingkan dengan kehamilan normal $(4,70 \pm 1,829) .^{3} \quad$ Leung dan Longtine, juga mendapatkan bahwa apoptosis meningkat signifikan sampai $4 \%(p<0.05)$ pada kelompok preeklampsia dibandingkan dengan peningkatan $1 \%$ pada kehamilan normotensi. ${ }^{14,15}$

Pada penelitian ini didapatkan rerata ekspresi Bax dan Bak pada wanita preeklampsia lebih tinggi dibandingkan dengan kehamilan normotensi.

Perbedaan yang ditunjukkan bermakna secara statistik $(p<0.05)$ dengan perbedaan rerata ekspresi protein Bax 0,23(KI 95\% 0,12 - 0,34) dan perbedaan rerata ekspresi protein Bak 0,44 (KI $95 \% 0,10-0,78)$. Salah satu keterbatasan pada penelitian ini adalah desain penelitian yang tidak melakukan matching dengan usia kehamilan. Dalam keadaan normal aktivitas apoptosis juga meningkat sesuai usia kehamilan, sehingga ekspresi Bax dan Bak dalam keadaan normal juga meningkat seiring bertambahnya usia kehamilan. Adanya perbedaan rerata usia kehamilan pada kedua kelompok dimana kelompok preeklampsia berat rerata usia kehamilan adalah 36 minggu sedangkan rerata usia kehamilan pada kelompok kehamilan normotensi adalah 38 minggu berperan pada perbedaan rerata ekspresi protein Bax dan Bak.

Review yang dilakukan Sharp, menyimpulkan bahwa apoptosis meningkat signifikan seiring dengan usia kehamilan, penelitian lain juga mendapatkan apoptosis terjadi pada plasenta kehamilan normal, pada trimester $\mathrm{I}=0,07 \%$ $(0.05 \%-0.14 \%)$ dan trimester III $=0.14 \%(0.09 \%$ to $0.20 \%)$, berbeda bermakna dengan $p<0,01$. Sehingga disimpulkan bahwa jumlah sel yang mengalami apoptosis berubah sesuai dengan usia kehamilan. ${ }^{16,17}$

\section{KELEMAHAN}

Kelemahan penelitian ini adalah tidak bisa dilakukan kontrol (matching) pada umur kehamilan saat pengambilan sample. Ekpsresi protein Bax dan Bakpada plasenta meningkatpada kehamilan normal seiring dengan bertambahnya 
usia kehamilan dan pada kehamilan dengan preeklampsia, IUGR, dan diabetes. ${ }^{12}$

\section{KESIMPULAN DAN SARAN}

Ekspresi protein Bax Dan Bak pada preeklampsia berat lebih tinggi dibanding dengan kehamilan normotensi dengan protein Bax yang lebih berpengaruh secara stastistik pada preeklampsia dibanding dengan protein Bak.

Penelitian lebih lanjut dengan sampel pasien eklampsia.

\section{DAFTAR PUSTAKA}

1. Babbette, D, Lamarca, Michael J., (2007), Pathophysiology of hipertension during preeclamsia: Role of inflamatory cytokines. Current hipetension review, 3, 69-74.

2. Soefoewan, S., (1998), Preeklampsia di Beberapa Rumah Sakit DI Indonesia, Patogenesis, dan Kemungkinan Pencegahan; Pidato Pengukuhan Jabatan Guru Besar pada Fakultas Kedokteran Universitas Gadjah Mada, Yogyakarta

3. Keman, K, presetyorini, N, Langgar, M.J., (2009), Perbandingan Ekspresi p53, bcl-2, dan indeks apoptosis trofoblas pada preeklampsia/eklampsia dan kehamilan normal, Maj Obstet Ginekol Indonesia, vol 33, No 3, Fakultas Kedokteran Universitas Brawijaya, Malang.

4. Robert, J.M., (2004), Pregnancy - Related Hypertension, Chapter 43, In : Resnik R, Creasy RK, Maternal - Fetal Medicine, Principle and Practice, Fifth Edition, p 859 - 899 Philadelphia, USA.

5. Park, J.K, Kang, M. Y., Kim, Y. H., Jo, H. C., Shin, J. K., Choi, W. J., Lee, S. a, et al., (2008), PKC delta in preeclamptic placentas promotes Bax dissociation from 14-3-3 zeta through 14-3-3 zeta phosphorylation. Placenta, 29(7), 584-92. doi:10.1016/j.placenta.2008.03.007.

6. Straszewski-Chavez, S.L, Abrahams, V.M, and Gil Mor., (2005), The Role of Apoptosis in The Regulation Of Trophoblast Survival and Differentiation During Pregnancy, Endocrine review 26 (7), p 877-97, Yale University School of Medicine, New Haven, USA.

7. Allaire, A.D., Ballenger, K.A., Wells, S.R, McMohan, M.J, and Lessey, B.A. (2000), Placental Apoptosis in
Preeclampsia, Obstetrics \& gynecology, vol 96, No 2, University of North Carolina at chapel hill, Chapel Hill, North Carolina.

8. Ruiz-vela, A, Opferman, J. T., Cheng, E. H., \& Korsmeyer, S. J., (2005), scientific report, Molecular Biology, 6(4), 2-8. doi:10.1038/sj.embor,7400375.

9. Hung, T.H, Chen, S.F, Liou, J.D, Shu, J.J, Lie, M.J, Yeh, Y.L, Hsieh, T.T., (2008), Bax, Bak and Mitochondrial Oxidants are Involved inHypoxia-reoxygenationinduced Apoptosis in Human Placenta; placenta 29, p 565-83, college of medicine, Chang Gung University, Taiwan.

10. Cuningham, F.G., McDonal, P.C., Gant, N.F., Levano, K.J., Gilstrap, L.C., and Hankins, G.D.V., (2010), Pregnancy Hypertension, In: William Obstetris, $23^{\text {th }}$, McGraw Hill Companies, p 706-47, NewYork.

11. Westphal D, Dewson G, Czabotar PE, Kluck RM, (2011) Molecular biology of Bax and Bak activation and action, Biochimica et Biophysica Acta, 1813, pp. 521-531.

12. Cobellis, L, et al., (2007), Modulation of Bax expression in physiological and pathological human placentas throughout pregnancy. In vivo (Athens, Greece), 21(5), 777-83.

13. Heazell A, Harris L, Forbes K, Crocker I. (2006) Placental cell turnover in health and disease, Reviews in Gynaecological and Perinatal Practice, 6, pp. 80-86.

14. Leung D, Smith SC, To KF, Sahota DS (2001) Increased Placental Apoptosis in Pregnancies Complicated by Preeclampsia, Am J Obstet Gynecol, 184, pp. 124950.

15. Longtine MS, Chen B, Odibo AO, Zhong $\mathrm{Y}$, Nelson DM (2012) Villous trophoblast apoptosis is elevated and restricted to cytotrophoblasts in pregnancies complicated by preeclampsia, IUGR, or preeclampsia with IUGR, Placenta, 33, 352-359.

16. Sharp AN, Heazell AEP, Crocker IA, Mor G (2010) Placental Apoptosis in Health and Disease, American Journal of Reproductive Immunology, 64, pp. 159-169.

17. Smith S, Baker PN, Symonds EM (1997) Placental apoptosis in normal human pregnancy, Am. J. Obstet. Gynecol., 177(1), pp. 57-64. 